\title{
Learning design for statistics materials using the context of traditional market assisted by interactive videos
}

\author{
Dina Lita Sari, Farida Nursyahidah * \\ Mathematics Education Study Program, Universitas PGRI Semarang, Central Java, Indonesia \\ ${ }^{*}$ Correspondence: faridanursyahidah@upgris.ac.id
}

(c) The Author(s) 2022

\begin{abstract}
Statistics is one of the mathematics subjects that can be useful in everyday life, especially data presentation material. However, many students still have difficulty understanding the data presentation material. So, it is necessary to design learning using the appropriate context and approach in learning data presentation material. Therefore, the researcher aims to determine student learning trajectories in understanding the presentation of statistical data using traditional markets as a context in the learning process using the Indonesian Realistic Mathematics Education (PMRI) approach assisted by interactive video. The research method used is the design research, which has three stages: the preliminary design stage, the experimental design stage (pilot experiment and teaching experiment), and the retrospective analysis stage. This study indicates that the learning trajectory obtained can help students understand the concept of data presentation material. The learning trajectory uses traditional market contexts and consists of 5 activities, namely: observing traditional market context learning videos and determining data, presenting data in the form of various tables, presenting data in the form of bar charts, presenting data in a line chart, presenting data in the form of pie charts and solving a contextual problem. Furthermore, the results of this study are expected to be an inspiration in learning using the context of everyday life.
\end{abstract}

Keywords: data presentation; design research; learning trajectory; PMRI; traditional market 


\section{Introduction}

Mathematics is one of the essential materials to learn, one of which is the presentation of statistical data. However, many students still have problems or difficulties in understanding statistical material. According to Maryati and Priatna (2017), the difficulties students face in statistical learning material are that they have difficulty recognizing and classifying data types and describing them in graphs or tables. Those students have difficulty concluding. Another opinion Sari and Bernard (2020) is that students experience conceptual problems in the form of errors in determining and using statistical formulas. Students forget the formulas that will be used, so that understanding concept in statistical material is fundamental to help students understand statistics. There is material for presenting data that is difficult for students to understand in statistics. Kumalasari and Sugiman (2015), Wari et al. (2020) said that students had difficulty in studying data presentation material (processing data). Students' difficulties in data presentation material include presenting data in line charts (Rosmiyati et al., 2015), reading data in the form of bar, line, and circle diagrams (Yuwono et al., 2016), and solving problems related to bar charts, line charts, and pie charts (Yuniati et al., 2014).

Various difficulties encountered were caused by monotonous explanations from the teacher. It is supported by Hartono et al. (2015) that teachers have problems in teaching statistics material; in presenting mathematics, learning is done monotonically with explanations from abstract to concrete concepts causing students to get bored in learning activities. Another problem faced, according to Ramadhani et al. (2013), is the lack of enthusiasm of students in the learning process and the lack of student activity or students being passive in the learning process. This opinion is supported by Prasetya et al. (2014), which say that Indonesia's learning process is still predominantly teacher-centered. However, the curriculum emphasizes demanding active student involvement in learning. However, many still use traditional learning, namely passive students, in the learning process. Students only receive knowledge or material presented by the teacher.

Some of the factors that cause student difficulties are the monotonous and teachercentered learning process. Previous research shows that the learning method used in statistical material is the only teacher-centered lecture method, with the media used in books and blackboards. It is supported by Sari (2017), who says that the learning of statistical material is only teacher-centered by explaining the material without allowing students to understand the material. Nadiyah et al. (2019) expressed a similar opinion and said that statistical material learning was carried out using the lecture method facilitated by books, whiteboards, and assignments through student worksheets. Another opinion expressed by Rahman (2018) said that students' conceptual understanding of statistical material is still relatively low because the method used by teachers uses the lecture method. So we need a learning approach that can improve students' understanding of concepts in statistical material by designing learning using an innovative learning approach using media and integrating the proper learning context, namely the PMRI (Indonesian Realistic Mathematics Learning) approach.

According to Putri et al. (2012), the PMRI approach has three principles, namely: (1) guided reinvention and progressive mathematization, (2) progressive mathematization, and (3) 
self-developed models. The principle in the PMRI approach is that there are activities to visualize real objects or the use of contexts around students' lives to advance to the most abstract level. A contextual approach in the learning process can help students understand the concept of the subject matter quickly and easily (Fahrurozi et al., 2018). In addition to the principles, the PMRI approach also has five characteristics according to Gravemeijer (1994), namely: (1) the use of context, (2) the use of models in progressive mathematics, (3) the use of student construction results, (4) interactivity, and (5) linkage.

PMRI approach directs students to find or build their concepts in the material being studied by implementing them in everyday life (Sari et al., 2017; Ahmad \& Asmaidah, 2017). Students learn mathematics starting from real things or real life to abstract mathematics. The PMRI approach that emphasizes context in learning creates a more meaningful learning process (Yusmanita et al., 2018). In addition, the PMRI approach can make students more motivated during the learning process and help students more easily understand the concepts of the material being studied (Nursyahidah et al., 2021; Lestari et al., 2021).

PMRI implementation process is carried out by linking the context of daily life with mathematics learning materials (Febriani et al., 2019). The context in PMRI is a real situation that can bridge formal mathematics into informal mathematics (Saefudin et al., 2012; Nursyahidah et al., 2018). Such as the traditional market context used in learning the material for presenting statistical data.

In traditional markets, sellers and buyers meet with direct transactions (Indrawati \& Yovita, 2014; Syarifudin et al., 2018). Students can observe traditional markets and count the number of traders with each type of merchandise which students can then present the data. Traditional markets were chosen by researchers to be used as learning contexts because traditional markets are places that are often visited and are familiar to the community, making it easier for students to observe and recognize the learning context. In addition, the selection of traditional market contexts is intended to invite students to explore and maintain local cultural wisdom that surrounds our daily lives.

The use of traditional markets as a context in learning statistics material integrated with technology or packaged in interactive learning videos has never been used in statistics learning before. Interactive videos are helpful to invite students to be active during the learning process and visualize the context used in learning. It is supported by Agustini and Ngarti (2020), who say that interactive learning videos can be used during the learning process because they can allow students to learn actively and help teachers explain the material being studied.

Several studies have conducted research related to statistical material learning. Still, they have not found a learning design for statistical data presentation material that integrates context in everyday life with technology. So it is necessary to design statistical material learning in the form of learning trajectories using traditional market contexts packaged in interactive videos. The learning trajectory is a series of activities used by teachers or researchers to develop students' thinking and make it easier to achieve learning objectives (Sitompul, 2018). Therefore, the purpose of this study was to determine the student's learning trajectory in learning to present statistical data using the context of traditional markets assisted by interactive videos. 


\section{Methods}

The method in this study uses design research methods. According to Gravemeijer and Van Eerde (2009), design research is a research method carried out in collaboration between teachers and researchers that aims to develop local instruction theory (LIT) to improve the quality of learning. A similar thing was expressed by Lestariningsih (2017), who said that design research was used to improve the quality of learning through repeated analysis, designing, and evaluating learning designs. This research has three stages: the preliminary design stage, the experimental design stage (pilot experiment and teaching experiment), and the retrospective analysis stage. However, this research is only limited to the pilot experiment stage in the experimental design stage due to the limited research time and pandemic conditions that do not allow learning to involve students in a whole class. This research was conducted at MTs Nurul Ulum Jembayat, Tegal Regency, Central Java, involving students of class VII B as subjects in this study. Subject selection was carried out in coordination with the subject teacher, determining six students with heterogeneous abilities, namely low, medium, and high abilities of two students, respectively, as seen from previous learning results.

This research begins with the preliminary design stage, namely the research preparation stage. At this stage, the researchers conducted a literature review from various journal articles and books, reviewed the curriculum on the essential competencies that students already had, the basic competencies needed, and student's understanding of concepts regarding learning materials. Besides, the researcher also prepared research instruments in contextual learning videos, pre-test questions, Student Activity Sheet (SAS), and post-test questions validated by mathematics education lecturers and then tested in the pilot experiment stage.

The next stage is the experimental design stage; this stage has two stages of research, namely the pilot experiment and the teaching experiment. The pilot experiment stage was carried out for six meetings starting from working on pre-test questions and student activity sheets with activity in one meeting. At this stage, data collection was carried out through observation, group discussions, student data collection, and pre-test implementation. , post-test and student interviews. Then a qualitative data analysis was carried out by comparing the results of observations during learning activities with the design of the learning trajectory that had been designed. Observations are made by observing the activities that occur during the learning process using an observation sheet that has been previously designed.

\section{Results}

This research results in the learning trajectory of data presentation material using a traditional market context assisted by interactive video. This learning trajectory consists of five activities. The first activity observed a traditional market learning video broadcast within 15 minutes with two views. The learning video can be accessed via the following link: https://youtu.be/1KwH86R-jCI. Students observe learning videos to write down data and present it in tabular form. The second activity is presenting data in various types of tables. Presenting the data in a bar chart is the third activity. The last activity is presenting the data in 
a line chart. The fifth activity presents data in the form of pie charts and solves contextual problems. Furthermore, the student learning trajectory is presented in Figure 1.

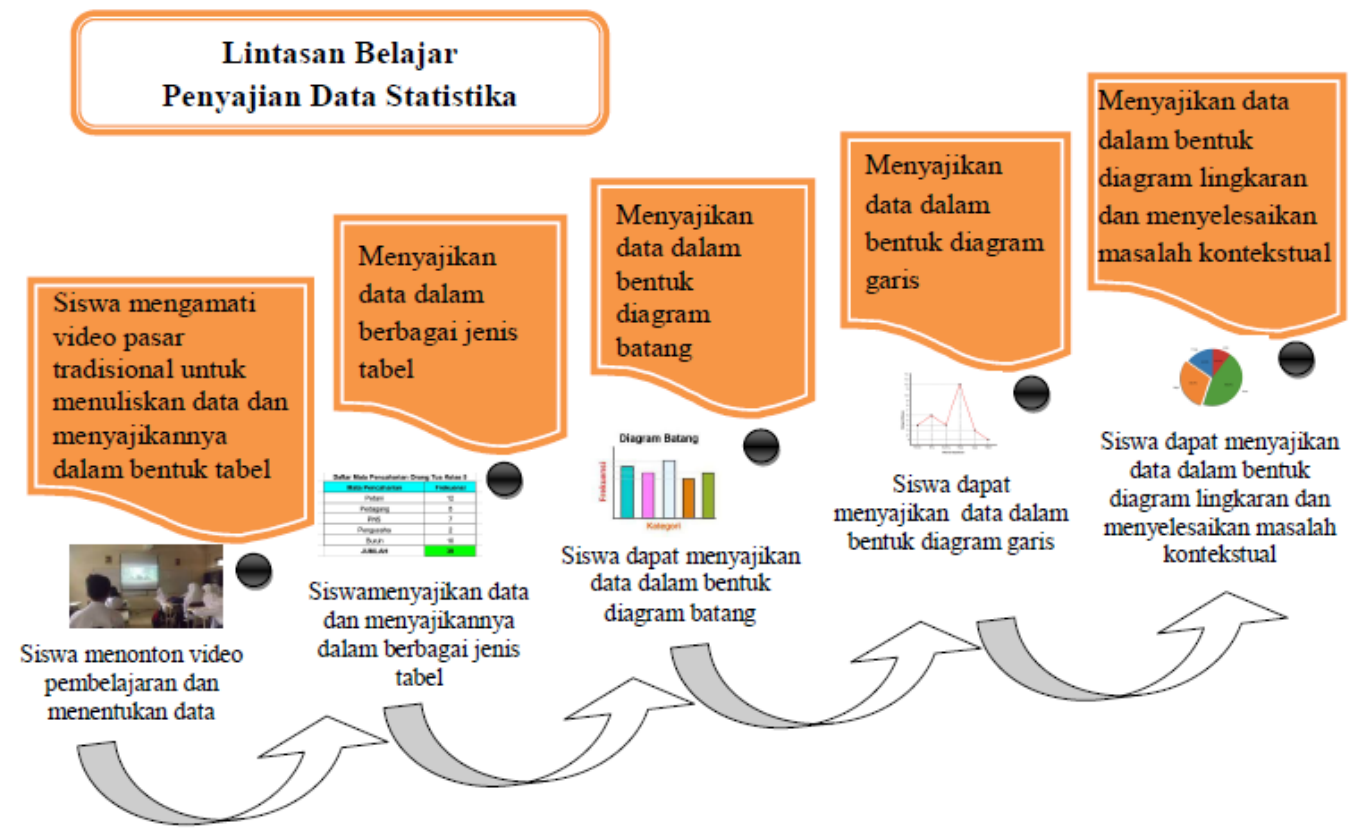

Translation:

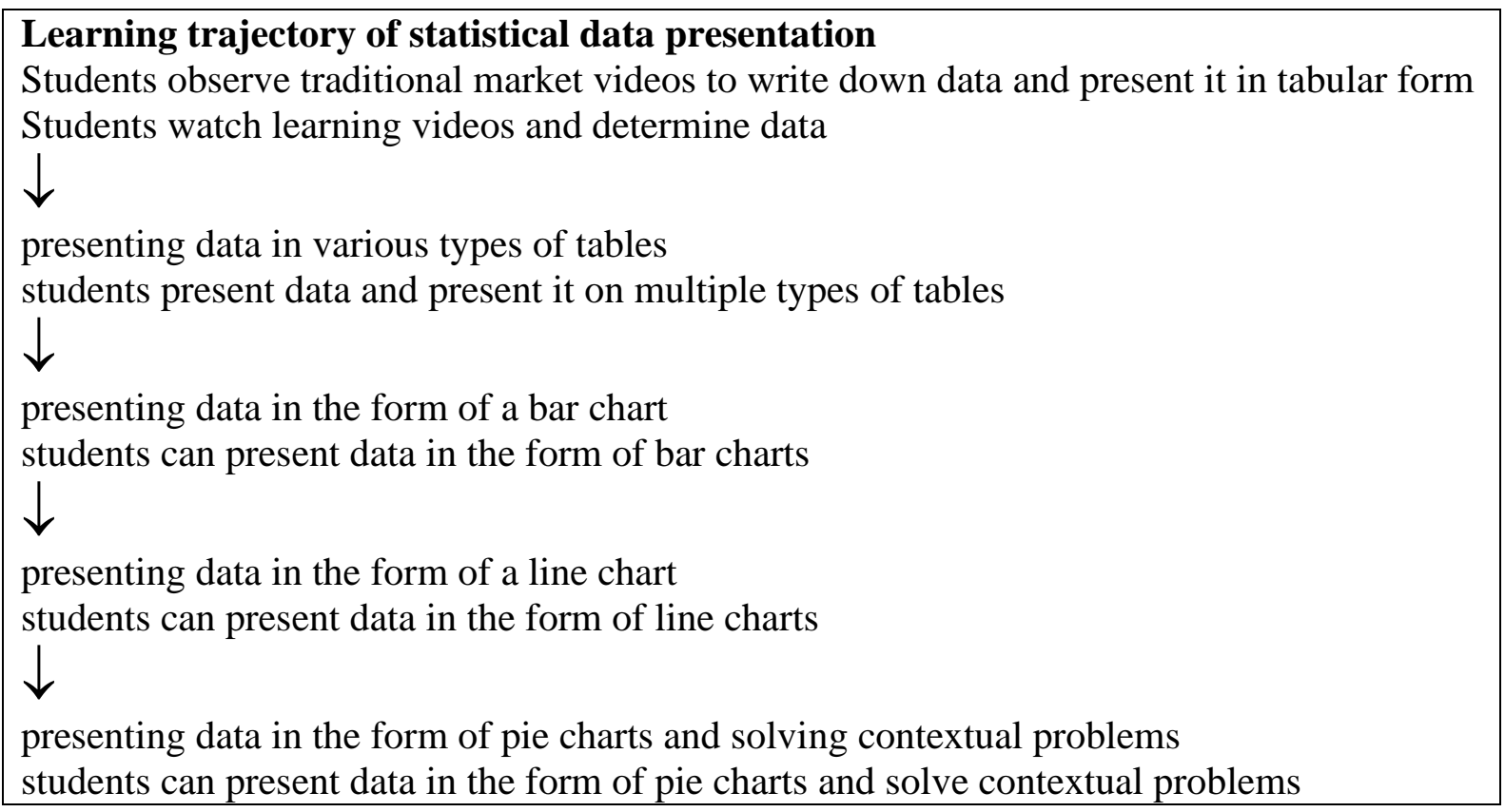

Figure 1. Student learning trajectory

A series of activities that have been designed can help students learn data presentation materials more easily using traditional market contexts in the form of interactive learning videos. It can be seen from students working on Student Activity Sheets, post-tests (final tests), and interviews. The description of the results of this study is presented as follows: 


\section{Activity 1: Watching traditional market learning videos and determining data}

In the first activity, the teacher starts learning by appreciating the material studied previously, namely data and tables, using a question-and-answer system. Then the teacher asks students to group according to high, medium, and low abilities guided by the teacher. After that, students were given SAS 1, which contained contextual questions related to the data. Then, students were asked to observe a traditional market contextual learning video that could be used to find data and present it in tabular form. Due to limited facilities and research sites, video viewing does not use an LCD projector but uses a laptop. The description of student activities observing traditional market learning videos is presented in Figure 2.

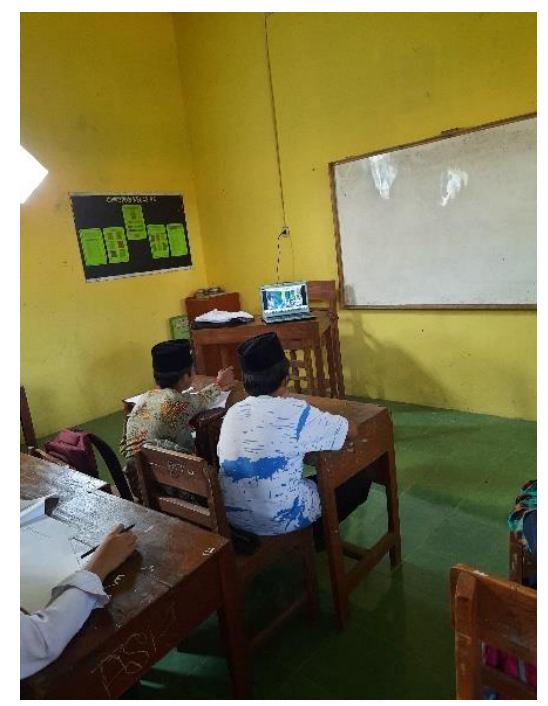

Figure 2. Student activities observing traditional market context learning videos

Then, students were asked to do SAS 1 with their respective groups. Using the traditional market context, students can easily define data, types of data, and obtain data. Students look active in discussing working on SAS 1. After finishing working on SAS 1, the teacher asks one group to present the results of their discussion and allows other students to think and comment if there are different results or things that have not been understood and provide reinforcement for the answers given. Be delivered. The following are the results of student answers in SAS 1, presented in Figure 3.

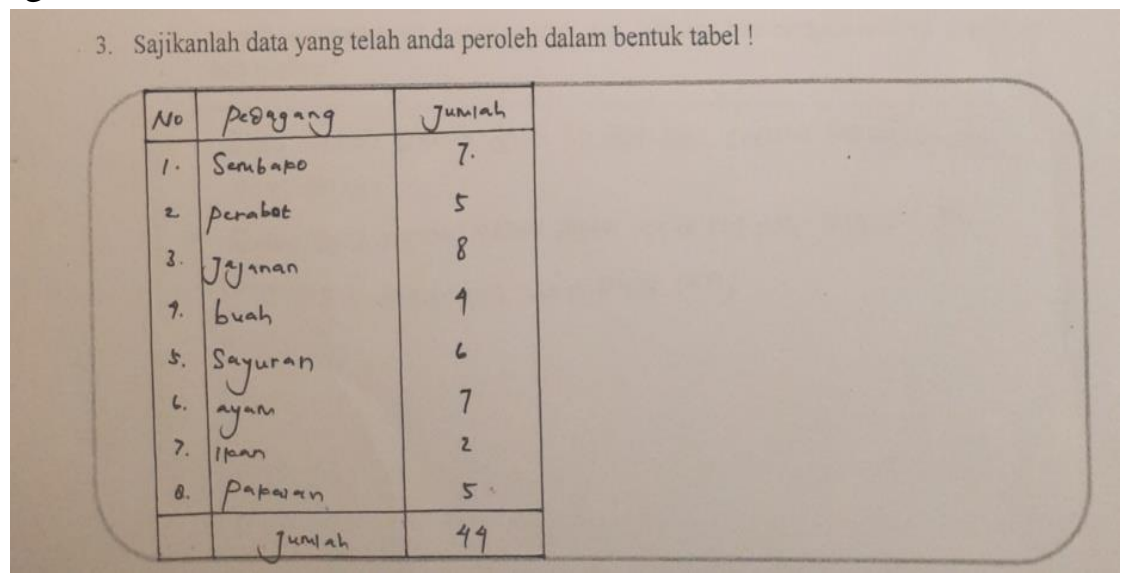


Translation:

\begin{tabular}{|clc|}
\hline \multicolumn{2}{c}{ Present the data you have obtained in the form of a table! } \\
\hline No & \multicolumn{1}{c}{ Merchant } & Total \\
\hline 1 & Groceries & 7 \\
2 & Furniture & 5 \\
3 & Snacks & 8 \\
4 & Fruits & 4 \\
5 & Vegetables & 6 \\
6 & Chicken & 7 \\
7 & Fish & 2 \\
8 & Clothes & 5 \\
\hline & Total & $\mathbf{4 4}$ \\
\hline
\end{tabular}

Figure 3. The results of students' answers in SAS 1

Based on Figure 3, it can be seen that students can write down the types of traders' sales and the amount of each in traditional markets through interactive learning videos that they watch. In addition, students present the data obtained in tabular form. So, it can be concluded that students can determine data, know how to obtain data, and present it in tabular form according to the objectives of the first learning activity.

\section{Activity 2: Presenting data in different types of tables}

In activity 2, students were given SAS 2 and asked to observe the contextual learning video of one of the basic food shops in the traditional market again. It can be seen that students are very enthusiastic in counting various types of items, and they are presented using the appropriate type of table. In this activity, students can distinguish different types of tables. The following results from students' answers in SAS 2 are presented in Figure 4.

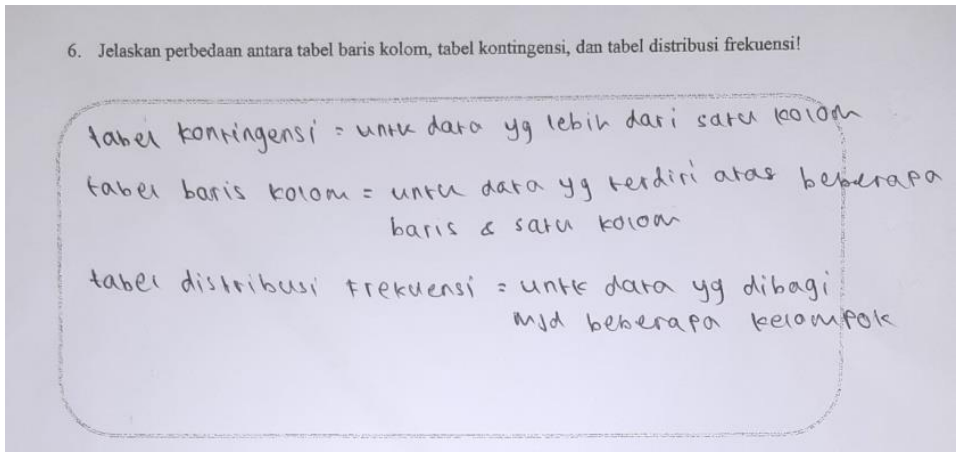

Translation:

Explain the difference between row column table, contingency table, and frequency distribution table!

Contingency table: for data with more than one column

Row column table: for data consisting of several rows and one column

Frequency distribution table: for data that is divided into several groups.

Figure 4. The results of students' answers in SAS 2

Based on the results of students' answers in Figure 4, it can be seen that students can distinguish between row and column tables, contingency tables, and frequency tables. Judging 
from the previous responses, students can also present data in tabular form. So it can be concluded that students can understand and distinguish between row and column tables, contingency tables, and frequency tables.

\section{Activity 3: Presenting data in the form of a bar chart}

In activity 3, students are given SAS 3 to work on with their respective groups. In this activity, students are given contextual problems and asked to present them in bar charts. Students can present data in bar charts, although there are obstacles in determining the frequency. After discussing with researchers through interviews, students can present bar charts correctly. Figure 5 shows the results of student answers in SAS 3.

Translation:

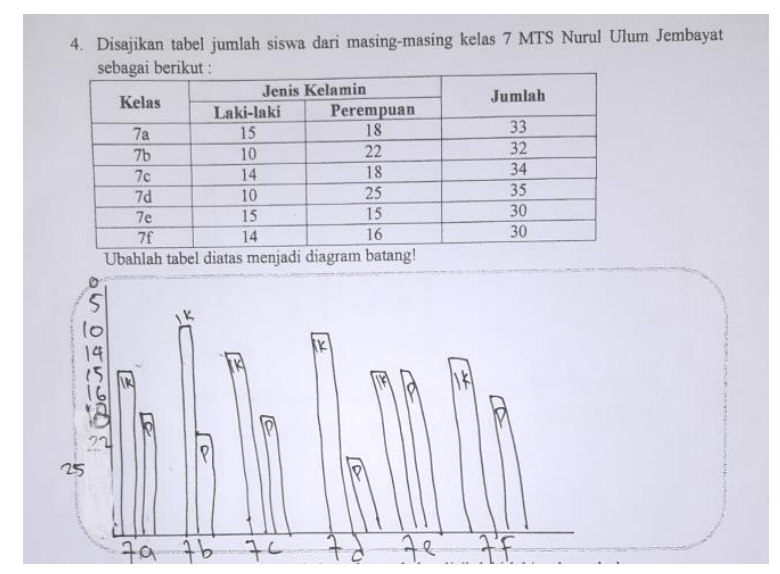

\begin{tabular}{|c|c|c|c|}
\hline \multicolumn{4}{|c|}{$\begin{array}{l}\text { A table of the number of students from each grade } 7 \text { of MTS Nurul } \\
\text { Jembayat is presented as follows! }\end{array}$} \\
\hline \multirow[b]{2}{*}{ Class } & \multicolumn{2}{|c|}{ Gender } & \multirow[b]{2}{*}{ Total } \\
\hline & Man & Woman & \\
\hline $7 \mathrm{a}$ & 15 & 18 & 33 \\
\hline $7 b$ & 10 & 22 & 32 \\
\hline $7 \mathrm{c}$ & 14 & 18 & 34 \\
\hline $7 d$ & 10 & 25 & 35 \\
\hline $7 e$ & 15 & 15 & 30 \\
\hline $7 f$ & 14 & 16 & 30 \\
\hline
\end{tabular}

Figure 5. The results of students' answers in SAS 3

Based on Figure 5, it can be seen that students are less precise in determining the frequency on the bar chart. As a result, the bar chart presented is inaccurate-student errors in determining the frequency from the highest to the lowest. The frequency should be written in order from the lowest to the highest. Explanation of students through interviews can be seen as follows:

P :"Take a look at the frequency written by Ms., and try to compare it with this graph (shows the graph of the question in LAS 1 no 7). Is there a difference?"

$\mathrm{N} \quad$ :Oh, this is zero from below, ma'am, while this one is from above."

A :"Yes, I forgot, it should be from the bottom."

$\mathrm{P} \quad$ :"That's right, starting from the lowest value to the highest value. Now, look at the range on the frequency, it should be the same, if the difference is 5, it means the distance must be the same between 5 to 10, 10 to 15, and so on.." 
$\mathrm{N} \quad$ :"Ma'am, for example, the value is 8; what does the point mean, ma'am?"

$\mathrm{P} \quad$ :'It is estimated, madam, if the frequency is made a multiple of 5, namely 5, 10, 15, and so on. Then you are asked to show a value of 8 which means the point is between 5 and 10, if you ask for a value of 6, it means that the point is at a frequency of 5 and above a little, about a value of 1. Like that, madam, can you understand?"

N :"Understood ma'am"

A :"For example, the value of 9 means less than 10, right, ma'am?"

P :"That's right, and so on. So the frequency is made in multiples for convenience."

Based on the interviews above, it can be concluded that students already understand the location of the error in writing the frequency, namely writing the difference in numbers. Moreover, it can write down the frequency from the lowest to the highest. So, it can be concluded that students can present data in bar charts.

\section{Activity 4: Presenting data in the form of a line chart}

In this activity, students were given SAS 4 and asked to read and examine each question. Then students were asked to observe the video learning context of traditional markets, but the object of observation this time was different; students observed fruit traders and were asked to write a list of fruit prices at one of the fruit traders in the Margasari market. Students can determine the data in this activity and present it in a line chart. The following results from student answers in SAS 4 are shown in Figure 6.

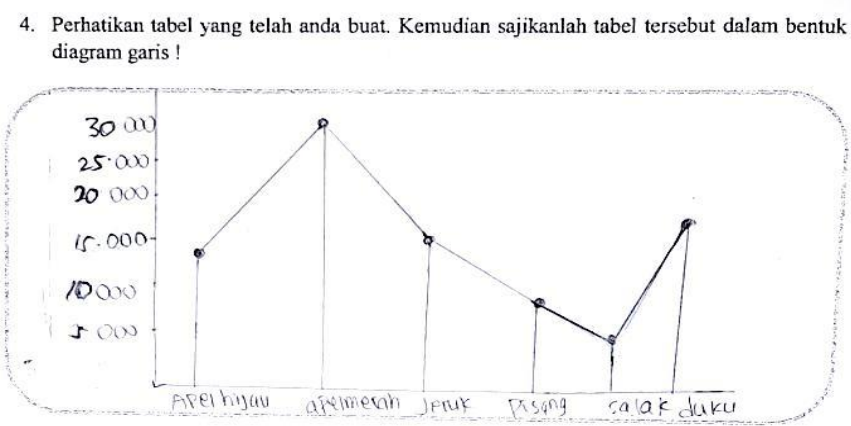

Translation:

Pay attention to the table you have created. Then present the table in the form of a line chart!

Figure 6. The results of students' answers in SAS 4

Based on the results of student answers in Figure 6, it can be seen that students can write down the frequency and difference correctly and can present the diagram correctly. So, it can be concluded that students can present data in the form of line diagrams. 


\section{Activity 5: Presenting data in the form of pie charts and solving contextual problems}

This activity is the last. Students were given SAS 5 and asked to read and examine each question. In SAS 5, students were given contextual problems that were still related to the context of traditional markets, namely data on various traders in traditional markets, and students determined the data and presented it in the form of pie charts. The results of student answers in SAS 5 can be seen in figure 7.

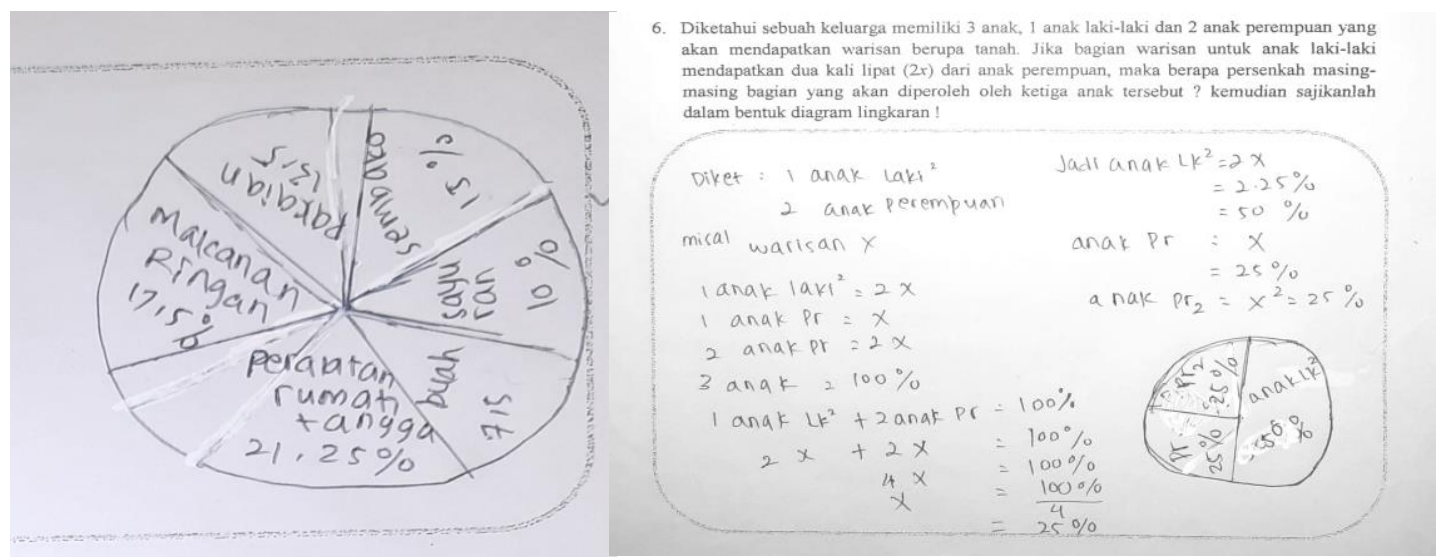

Translation:

\begin{tabular}{|l|l|}
\hline Pie Chart & It is known that a family has 3 children, 1 son and 2 daughters \\
Snacks: $17.5 \%$ & who will continue the inheritance in the form of land. If the share \\
Clothes: $12.5 \%$ & of the inheritance for the son gets double $(2 \mathrm{x})$ than the daughter, \\
Groceries: $15 \%$ & then what percentage of each share will the three children get? \\
Vegetables: $10 \%$ & Then present it in the form of a pie chart! \\
Fruits: $7.5 \%$ & Known: 1 son, 2 daughters \\
Furniture: $21.25 \%$ & Example: 1 inheritance \\
& 1 son=2x \\
1 daughter $=\mathrm{x}$ \\
2 daughters $=2 \mathrm{x}$ \\
2 children $=100 \%$ \\
1 son +2 daughters $=100 \%$ \\
$2 \mathrm{x}+2 \mathrm{x}=100 \%$ \\
& $4 \mathrm{x}=100 \%$ \\
& $\mathrm{X}=100 \% / 4$ \\
& $\mathrm{X}=25 \%$ \\
& Therefore, son $=2 \mathrm{x}=2 \mathrm{x} 25 \%=50 \%$ \\
& Daughter $=\mathrm{x}=25 \%$ \\
& 2 daughters $=\mathrm{x}^{2}=25 \%$ \\
\hline
\end{tabular}

Figure 7. Results of student answers in SAS 5

Figure 7 shows that students can present data in pie charts based on students' answers. Students determine the percentage correctly and write down the name of each trader. In addition, from the figure, it can be seen that students can solve given contextual problems related to data presentation. So, it can be concluded that students can present data in the form of pie charts and solve contextual problems related to data presentation. 


\section{Discussion}

The preliminary design stage produces instruments used in research such as pre-test, post-test, SAS, interactive learning videos, and Hypothetical Learning Trajectory (HLT). The learning trajectory is designed to determine students' stages of understanding the learning material being studied. It is supported by Ayunika (2011), who revealed that the learning trajectory could build students' understanding of the concepts of the material being studied. A similar opinion was expressed by Gee (2019), and Nursyahidah et al. (2020) said that a series of activities in the learning trajectory could develop students' thinking skills in building the concept of the material being studied.

The pilot experiment stage produces student work results at each stage, including the pretest stage. It is seen that some students can work on the questions but the answers written are still not correct. It is because students have not received the material being studied. In the first activity, students observe the video context of traditional market learning and can determine the type of sales data for traders and present it in tabular form. In the second activity, students present data in tabular form and distinguish between different tables. In the third activity, students can present bar charts, although there are difficulties in presenting them; after conducting interviews, students can solve their problems. It is similar to Yuwono's opinion (2016), who said that students have difficulty presenting bar charts. Activity 4 is that students can present inline data charts. In Activity 5, students can present data in pie charts and solve contextual problems. In working on the post-test questions, it can be seen that the results written by students are better than the results of working on the pre-test questions.

The retrospective analysis stage produces a learning trajectory that follows the student's abilities by revising the learning trajectory in terms of the student's work compared with the initial design of the learning trajectory. Furthermore, the resulting learning trajectory can be used at the teaching experiment stage.

\section{Conclusion}

The resulting learning trajectory consists of five activities: observing traditional market context videos to determine data, presenting data in tabular form, presenting data in bar chart form, presenting data in line chart form, and presenting data in pie charts, and solving contextual problems. The results show that a series of activities designed in the form of a learning trajectory in the context of a traditional market with the help of interactive videos can help students stimulate the understanding of statistical data presentation concepts and create meaningful learning. However, the learning trajectory still needs to be tested in the teaching experiment stage, which involves a whole class of students to obtain a better learning trajectory. 


\section{Conflicts of Interest}

The authors declare that no conflict of interest regarding the publication of this manuscript. In addition, the ethical issues, including plagiarism, misconduct, data fabrication and/or falsification, double publication and/or submission, and redundancies have been completely by the authors.

\section{References}

Agustini, K., \& Ngarti, J. G. (2020). Pengembangan video pembelajaran untuk meningkatkan motivasi belajar siswa menggunakan model R\&D [Development of learning videos to increase students' learning motivation using the R\&D model]. Jurnal Imiah Pendidikan dan Pembelajaran, 4(1), 62-78.

Ahmad, M., \& Asmaidah, S. (2017). Pengembangan perangkat pembelajaran matematika realistik untuk membelajarkan kemampuan pemecahan masalah matematika siswa SMP [Development of realistic mathematics learning tools to teach math problem solving skills of junior high school students]. Mosharafa: Jurnal Pendidikan Matematika, 6(3), 373384. https://doi.org/10.31980/mosharafa.v6i3.326

Ayunika, E. (2011). Pengembangan hipotesis trayektori pembelajaran untuk konsep pecahan. Pendidikan Matematika Universitas Sanata Dharma

Fahrurozi, A., Maesaroh, S., Suwanto, I., \& Nursyahidah, F. (2018). Developing learning trajectory based instruction of the congruence for ninth grade using central java historical building. JRAMathEdu (Journal of Research and Advances in Mathematics Education), 3(2), 78-85. https://doi.org/10.23917/jramathedu.v3i2.6616

Febriani, P., Widada, W., \& Herawaty, D. (2019). Pengaruh pembelajaran matematika realistik berbasis etnomatematika terhadap kemampuan pemahaman konsep matematika siswa SMA kota Bengkulu [The effect of ethnomathematical-based realistic mathematics learning on the ability to understand mathematical concepts of Bengkulu City High School students]. Jurnal Pendidikan Matematika Raflesia, 4(2), 120-135. https://doi.org/10.33449/jpmr.v4i1.7530

Gee, E. (2019). Kemampuan pemecahan masalah matematika melalui alur belajar berbasis realistic mathematics education (RME) [Mathematics problem solving ability through realistic mathematics education (RME) based learning flow]. Jurnal Education and Development, 7(3), 269-269.

Gravemeijer, K. \& Van Eerde, D. (2009). Design research as a means for building a knowledge base for teacher and teaching in mathematics education. The Elementary School Journal, 109(5), 510-524. https://doi.org/10.1086/596999

Gravemeijer, K. (1994). Developing realistic mathematics education. Freudenthal Institute.

Hartono, Y., \& Santoso, B. (2015). Desain pembelajaran berbasis proyek pada materi penyajian data di kelas IX [Project-based learning design on data presentation material in class IX]. Numeracy, 2(2), 1-12.

Indrawati, T., \& Yovita, I. (2014). Analisis sumber modal pedagang pasar tradisional di kota Pekanbaru [Analysis of the source of capital for traditional market traders in the city of Pekanbaru]. Jurnal Ekonomi, 22(01), 1-8.

Kumalasari, A., \& Sugiman, S. (2015). Analisis kesulitan belajar mahasiswa pada mata kuliah kapita selekta matematika sekolah menengah [Analysis of student learning difficulties in high school mathematics selecta capita courses]. Jurnal Riset Pendidikan Matematika, 2(1), 16-27. https://doi.org/10.21831/jrpm.v2i1.7147 
Lestari, A. A. P., Nugroho, A. A., \& Nursyahidah, F. (2021). Desain pembelajaran refleksi dan translasi berkonteks Klenteng Sam Poo Kong Semarang [Reflection and translation learning design in the context of Sam Poo Kong Temple Semarang]. Jurnal Elemen, 7(2), 381-393. https://doi.org/10.29408/jel.v7i2.3400

Lestariningsih. (2017). Desain pembelajaran transformasi menggunakan motif batik tulis Sidoarjo [Transformation learning design using Sidoarjo batik motifs]. Jurnal Edukasi, 3(1), 83-98.

Maryati, I., \& Priatna, N. (2017). Analisis kesulitan dalam materi statistika ditinjau dari kemampuan penalaran dan komunikasi statistis [Analysis of difficulties in statistical material in terms of statistical reasoning and communication skills]. Prisma, 6(2), 173179. https://doi.org/10.35194/jp.v6i2.209

Nadiyah, S., Wijaya, F. Y., \& Hakim, A. R. (2019). Desain komik strip matematika pada materi statistika untuk kelas VI tingkat sekolah dasar [Mathematical comic strip design on statistics material for grade VI elementary school level].JKPM (Jurnal Kajian Pendidikan Matematika), 4(2), 135-146. https://doi.org/10.30998/jkpm.v4i2.3870

Nursyahidah, F, Saputro, B. A., \& Rubowo, M. R. (2018). Supporting second grade lower secondary school students understanding of linear equation system in two variables using ethnomathematics. Journal of Physics: Conference Series, 983(1), Article 012119. https://doi.org/10.1088/1742-6596/983/1/012119

Nursyahidah, F., Saputro, B. A., Albab, I., \& Aisyah, F. (2020). Pengembangan learning trajectory-based instruction materi kerucut menggunakan konteks Megono Gunungan [Development of learning trajectory-based instruction on cone material using the context of Megono Gunungan]. Mosharafa: Jurnal Pendidikan Matematika, 9(1), 47-58. https://doi.org/10.31980/mosharafa.v9i1.560

Nursyahidah, F., Saputro, B. A., \& Albab, I. U. (2021). Desain pembelajaran kerucut berkonteks tradisi Megono Gunungan [Cone learning design in the context of the Megono Gunungan tradition]. Jurnal Elemen, 7(1), 14-27. https://doi.org/10.29408/jel.v7i1.2655

Prasetya, S. P. (2014). Memfasilitasi pembelajaran berpusat pada siswa [Facilitate studentcentered learning]. Jurnal Geografi, 12(1), 1-12. https://doi.org/10.21009/SPATIAL.122.01

Putri, R. I. I. (2012). Pembelajaran materi bangun datar melalui cerita menggunakan pendekatan pendidikan matematika realistik indonesia (PMRI) di sekolah dasar [Learning flat shape material through stories using the Indonesian Realistic Mathematics Education (PMRI) approach in elementary schools]. Jurnal Pendidikan dan Pembelajaran (JPP), 18(2), 235-240.

Rahman, A. A. (2018). Penerapan pendekatan realistic mathematics education (RME) pada materi statistika untuk meningkatkan pemahaman konsep dan prestasi belajar siswa [Application of realistic mathematical education (RME) approach to statistics material to improve understanding of concepts and student achievement]. GENTA MULIA: Jurnal Ilmiah Pendidikan, 8(2), 1-12. https://ejournal.stkipbbm.ac.id/index.php/gm/article/view/114

Ramadhani, F., Santosa, S., \& Ngadiman, D. (2013). Upaya peningkatan kualitas pembelajaran akuntansi melalui model pembelajaran berbasis projek (project based learning) [Efforts to improve the quality of accounting learning through project-based learning models]. Jupe-Jurnal Pendidikan Ekonomi, 1(1), 1-12.

Rosmiyati, R., \& Afrahamiryano, A. (2015) Analisis kesulitan mahasiswa jurusan PMIPA dalam pengolahan data statistik [Analysis of the difficulties of PMIPA majoring students in statistical data processing]. Lemma: Letters of Mathematics Education 1(2), 52-56. http://ejournal.stkip-pgri-sumbar.ac.id/index.php/jurnal-lemma/article/view/537 
Saefudin, A. A. (2012). Pengembangan kemampuan berpikir kreatif siswa dalam pembelajaran matematika dengan pendekatan pendidikan matematika realistik indonesia (PMRI) [Development of students' creative thinking skills in learning mathematics with the Indonesian realistic mathematics education approach (PMRI)].Al-Bidayah: Jurnal Pendidikan Dasar Islam, 4(1), 37-48.

Sari, S. K. (2017). Pengembangan desain pembelajaran statistika berbasis it menggunakan pendekatan realistic mathematics education untuk kelas VIII SMP [Development of an IT-based statistical learning design using a realistic mathematics education approach for VIII junior high school class. JNPM (Jurnal Nasional Pendidikan Matematika), 1(2), 290-304. https://doi.org/10.33603/jnpm.v1i2.495

Sari, D. R., \& Bernard, M. (2020). Analisis kesalahan siswa SMP dalam menyelesaikan soal materi statistika di Bandung Barat [Analysis of junior high school students' errors in solving statistical problems in West Bandung]. Journal of Medives: Journal of Mathematics Education IKIP Veteran Semarang, 4(2), 223-232. https://doi.org/10.31331/medivesveteran.v4i2.1060

Sitompul, S. H. (2018). Pengembangan lintasan belajar siswa dalam pembelajaran segitiga dengan menggunakan pendekatan kontekstual di kelas VII MTs N 2 Padangsidimpuan [Development of student learning trajectories in triangle learning using a contextual approach in class VII MTs N 2 Padangsidimpuan] [Unpublished doctoral dissertation]. IAIN Padangsidimpuan.

Syarifuddin, D. (2018). Pasar tradisional dalam perspektif nilai daya tarik wisata [Traditional markets in the perspective of tourist attraction values]. Jurnal Manajemen Resort dan Leisure, 15(1), 19-32.

Wari, C. P., Monica, D. S., \& Ramadani, W. F. (2020). Analisis kesulitan belajar siswa SMPN 1 Bengkulu Tengah kelas VII melalui diagnotik pada penyajian data [Analysis of learning difficulties for students of SMPN 1 Bengkulu Tengah class VII through diagnostics on data presentation]. JPT: Jurnal Pendidikan Tematik, 1(3), 123-129.

Yuniati, S. (2014). Analisis kesalahan mahasiswa dalam menyelesaikan soal pembuktian struktur aljabar [Analysis of student errors in solving algebraic structure proof problems]. Beta: Jurnal Tadris Matematika, 7(2), 72-81.

Yusmanita, S., Ikhsan, M., \& Zubainur, C. M. (2018). Penerapan Pendekatan matematika realistik untuk meningkatkan kemampuan operasi hitung perkalian [Application of a realistic mathematical approach to improve the ability of multiplication arithmetic operations]. Jurnal Elemen, 4(1), 93. https://doi.org/10.29408/jel.v4i1.469

Yuwono, M. R. (2016). Analisis kesulitan mahasiswa dalam menyelesaikan soal geometri berdasarkan taksonomi Bloom dan alternatif pemecahannya [Analysis of student difficulties in solving geometry problems based on Bloom's taxonomy and alternative solutions]. Beta: Jurnal Tadris Matematika, 9(2), 111-133. https://doi.org/10.20414/betajtm.v9i2.7 